US oceanography

\section{Research centre born in storm}

\section{Washington}

THE US Navy's new Institute for Naval Oceanography (INO) in Bay St Louis, Mississippi, opened last month with ambitions of becoming the leading ocean modelling research centre in the 1990s. But critics are still bitter at the decision by the Navy to put the institute at the unpopular Mississippi site rather than at Monterey, California, the choice of the great majority of the experts consulted. Some say that the Mississippi site, which is far from any major university and suffers from extreme heat and humidity in the summer, will be a "major impediment" to hiring the best researchers in the field.

According to consultants who worked on the project, Bay St Louis was not even the first choice of Secretary of the Navy John Lehman. The final decision was not made until 18 months ago, and many see it as reflecting the influence of Mississippi Senator John Stennis, a powerful Democrat on the Senate Armed Services Committee. Stennis is seen as the force behind a long-term agglomeration of Navy oceanographic facilities at Bay St Louis.

Some oceanographers say that opportunities for INO collaboration with the Navy's Fleet Numerical Oceanographic Center and its postgraduate school at Monterey would have been better than with the Navy Oceanographic Research and Development Activity (NORDA), already at the Bay St Louis site. (Researchers staged a protest several years ago when part of the Naval Research Laboratory in Washington was moved to Bay St Louis to become part of NORDA.) And the Monterey climate is as famed for being pleasant as that of the Mississippi delta is for being unpleasant.

Even so, a member of Stennis's staff denies that political pressure had been brought to bear, saying the decision reflected priorities decided by the Navy several years ago.

INO will work on all aspects of ocean modelling and prediction, using supercomputers at other centres until it acquires in about two years its own 'class 7' supercomputer, the generation beyond the most advanced Cray machine, the XMP 4800.

Although the centre was formed primarily to improve predictions for naval operations, its director, Christopher Mooers, foresees many spin-offs to civilian applications. At present, ocean predictions are limited by atmospheric variability, and a major goal will be to integrate atmospheric data with oceanic models. Mooers says that working at INO will "appeal to those with a pioneering spirit".

The immediate goal, for the year or so ahead, is to provide regional predictions. The centre will be fully operational in the early 1990 s. The institute is timed to make best use of the expected welter of new remote-sensing ocean data in the next decade, when the National Aeronautics and Space Administration's TOPEX satellite will be in service and the US Navy launches its NROSS oceanographic satellites. Walter Munk, chairman of the National Academy of Sciences' ocean studies board, endorses the formation of the institute, saying of ocean modelling that "noone knows yet how well it can be done". INO will also integrate data from acoustic sensors and in situ measurements.

INO has been established at the National Space Technology Laboratories, a

\section{Soviet Union}

THE election of Academician Gurii Marchuk as president of the Soviet Academy of Sciences has been celebrated with massive self-criticism. Instead of dwelling on recent achievements, both the report on the state of the academy presented by vice-president Vladimir Kotel'nikov and the ensuing discussion stressed deficiencies in performance ranging from overstaffing with inept personnel to a shortage of computers of "average productivity".

In some cases, although no names were mentioned, the faults seem to have been at least in part associated with the attitude of the outgoing president, Anatolii Aleksandrov, towards Western science. It was Aleksandrov's contention that Soviet science can achieve world leadership in all fields on its own efforts, and that Soviet participation in international cooperation programmes should be undertaken only to further detente and to avoid duplication of effort. Now, however, Kotel'nikov's report stresses that the CoCom restrictions on the transfer of Western state-of-the-art instruments constitutes a serious problem and the Soviet instrument manufacturing industry cannot satisfy the needs of the scientific community. Some time ago, said Kotel'nikov, the academy raised the question of how to expand the development and manufacture of scientific instruments but it has made little progress so far, although capital investment in the academy's own instrument-making base is to increase by 150 per cent during the present five-year plan.

Similarly, Academician Boris Paton, president of the Ukrainian Academy of Sciences, urged the importance for Soviet planners of a proper understanding of technological developments in the West. Although technology is "the most holy of holies to which there is virtually no access", Soviet scientists must use all "possi-

remnant of the Apollo space programme, with an initial budget of $\$ 4$ million and a staff of 30 . It is expected to expand to about 50 within five years, and will set aside about $\$ 1$ million each year to support work at other institutions. Mooers specifically welcomes proposals for collaborative research with overseas scientists.

Many academic oceanographers say quality suffers at Navy-run establishments, partly because military directors are often on short-term appointments. Mooers says that the NCAR consortium "provides our academic quality assurance". But other oceanographers are more cautious, saying the institute's potential to become a world leader will be met only if the Navy resists the temptation to keep it focused on short-term goals.

Tim Beardsley

\title{
Russian criticism begins at home
}

ble and, so to say, impossible" means of establishing this information.

Paton's suggestions raise a number of interesting questions. The Soviet Union already has an extensive information network, administered, in the civil sector, by the State Committee for Science and Technology, and in the military sector by the Commission for the Defence Industry. Information on Western science and (in particular) technology, obtained by debriefing scientists returning from visits abroad, is fed into these twin networks through their permanent representatives in the research institutes. The reverse engineering of Western prototypes coming into Soviet hands is likewise carried out under the auspices of these bodies. What Paton appears to imply, therefore, is that either the academy scientists have not been sufficiently zealous in their efforts to acquire useful technological information, or that the analysis carried out by the existing information services is inadequate.

As far as Soviet science is concerned, most criticisms proved to be aspects of the endemic Soviet theme: the failure to implement research results in manufacturing and agricultural practice.

But some practical suggestions were proposed. Academician Vladimir Tuchkevich noted that, although academic resesearch institutes are encouraged to serve the needs of industry, they have no financial incentive to do so. Instead, the research is financed by the state, and the results, including any hardware produced by the research team, either have to be handed over free of charge or sold at less than cost price. It would be better, Tuchkevich urged, if the research institute could charge industry for what it has produced, return the initial investment to the statae, and use the profits for its own needs.

Vera Rich 